
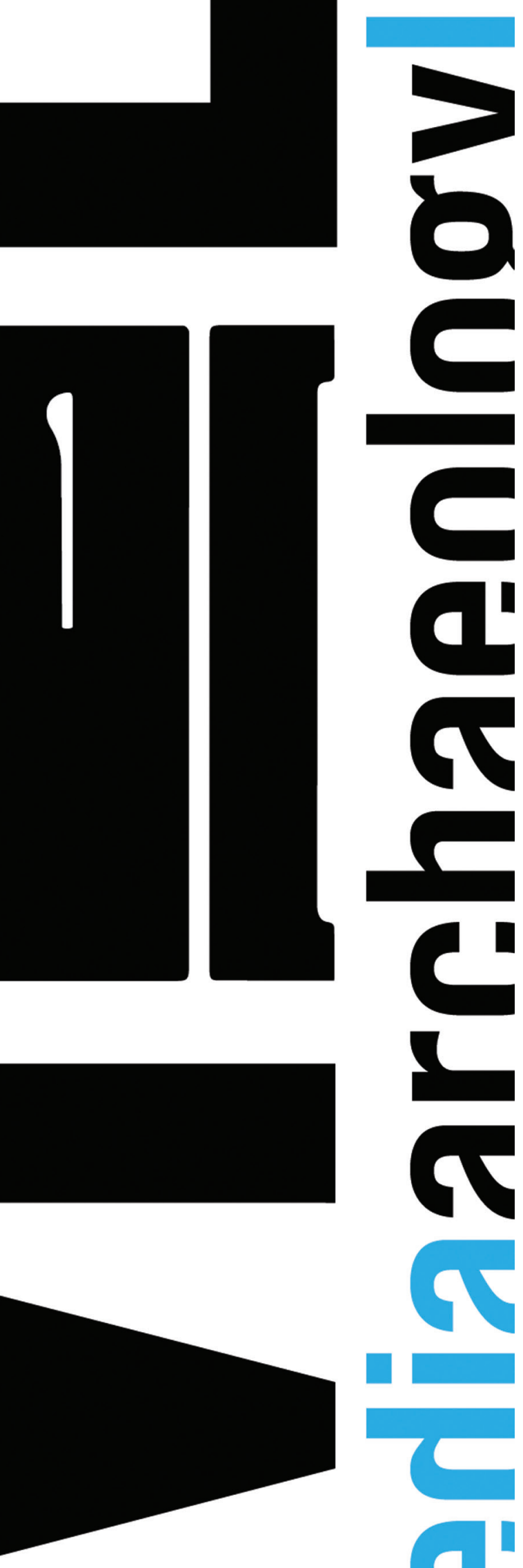

\section{The Media Archaeology} Lab (MAL, University of Colorado Boulder, USA) as an Archive

El Laboratorio de Arqueología de Medios (MAL, Media

Archaeology Lab, University of Colorado Boulder, EUA)

como archivo

\section{Lori Emerson}

Media Archaeology Lab (MAL)

University of Colorado Boulder (CU-Boulder), Estados Unidos de América

Lori.Emerson@colorado.edu

\section{Resumen}

Fundadora y directora del Media Archaeology Lab (MAL, Laboratorio de Arqueología de Medios), Universidad de Colorado-Boulder (CU-Boulder), Estados Unidos de América (EUA), Lori Emerson discute tanto la historia de esta organización del 2008 a la fecha como su filosofía flexible de uso y acceso vivencial a los llamados "viejos medios" con la finalidad de enseñar, investigar y desarrollar prácticas artísticas. Emerson, también ofrece una SEMBLANZA de las colecciones de este laboratorio, sus proyectos de investigación y sus residencias artísticas, todas ellos componentes esenciales de la vocación del MAL.

\section{Palabras clave}

viejos medios; laboratorio; literatura digital; investigación aplicada; arqueología de medios

\section{Abstract}

Founder and Director of the Media Archaeology Lab (MAL) University of Colorado-Boulder (CUBoulder), United States of America (USA), Lori Emerson discusses both its history from 2008 to the present and its flexible philosophy of using hands-on access to so-called "old media" as a way to drive teaching, research, and artistic practice. Emerson also provides an OVERVIEW of this laboratory's holdings, research projects as well as the artist residencies, all of them essential elements for MAL's mission.

\section{Keywords}

old media; laboratory; digital literature; practice-based research; media archaeology 


\section{Introduction}

$\mathrm{T}$ he Media Archaeology Lab (MAL) came to life in 2008-2009 at the Colorado University at Boulder (CU-Boulder), Colorado, United States of America (USA). At that time, the field of media archaeology had not yet become well known in North America and the lab was nothing more than a small room on the university campus that contained fifteen Apple $\mathrm{Il}^{\Theta}$ computers, floppy drives, and copies on 5.25" floppy disks of a work I had come to admire very much: First Screening (bpNichol 1983), one of the first (if not the first) digital kinetic poems created by the Canadian experimental poet bpNich$\mathrm{ol}^{1}$ (Figures 1 and 2). I began the lab, then, partly because I wanted to start experimenting with stockpiling hardware and software as a complimentary preservationist strategy to creating emulations such as the one of First Screening that had recently been made available. Without being aware of the very nascent debates in digital archivist communities in the USA and Canada (LV 2013) that were then pitting emulation against original hardware/software, I wanted to augment students' and scholars' access to early works of digital literature and art while also collecting other works and their original platforms in order to eventually make available emulations of these works.
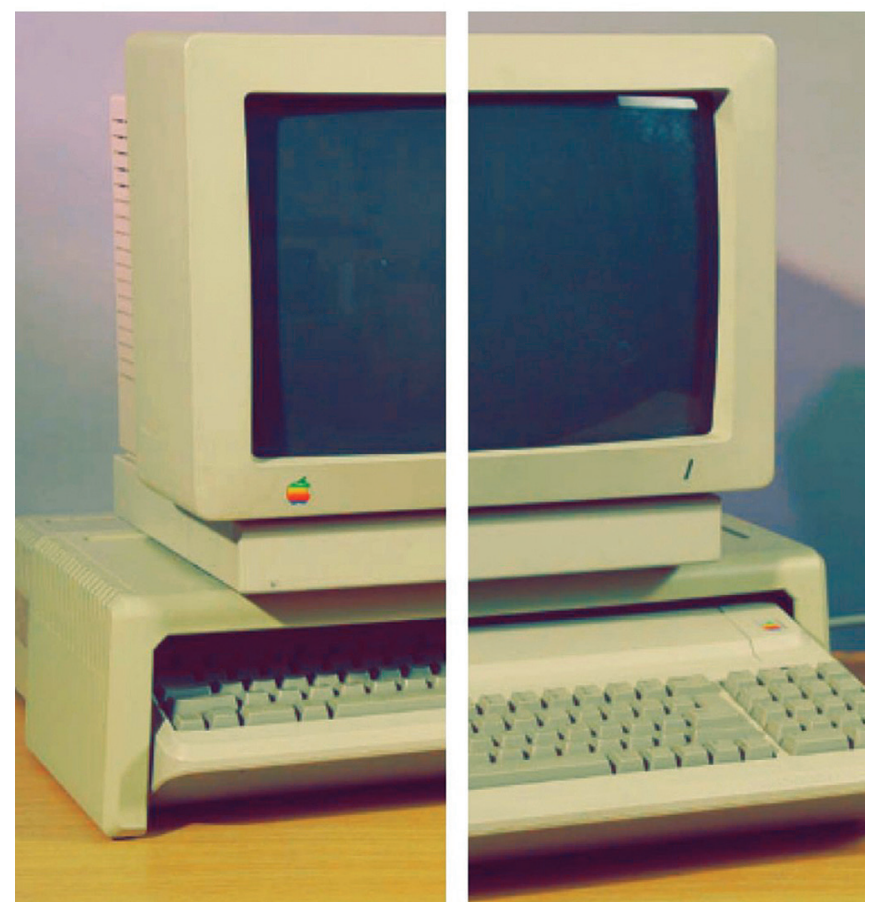

FIGURE 1. Apple Ile@ computer. (Photograph: Diane Bolluck, 2012; courtesy: The Media Archaeology Lab, CU-Boulder).

\footnotetext{
${ }^{1}$ While the importance of bpNichol (1944-1988) for this essay is his digital poem, First Screening, he was also a prolific writer of bookbound works; he is particularly well known for The Martyrology, a long poem encompassing nine books in six volumes.
}

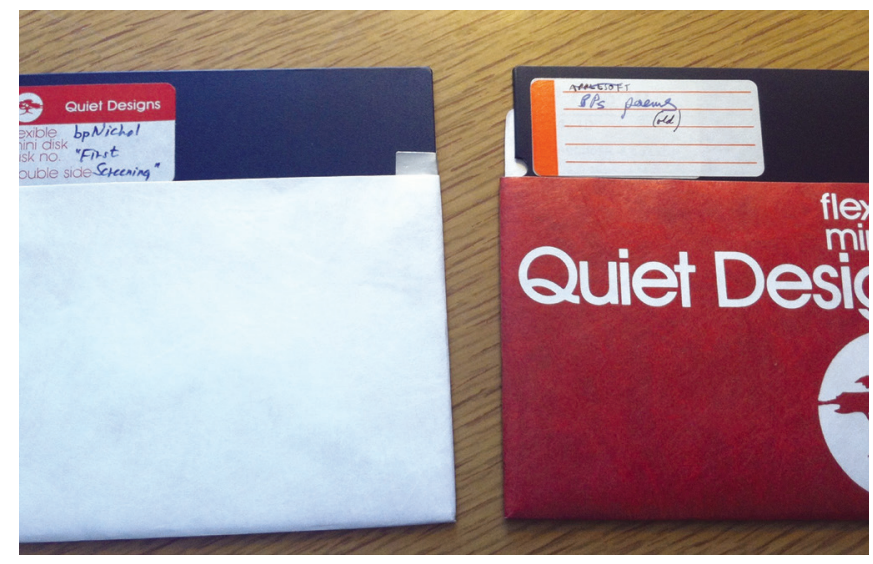

FIGURE 2. 5.25" floppies of bpNichol's First Screening. (Photograph: Lori Emerson, 2012; courtesy: the Media Archaeology Lab, CU-Boulder).

However, I also created the lab because I wanted to bring in small undergraduate and graduate classes to work directly on the machines, with the original work by bpNichol, rather than only study the emulated version. In other words, the lab allowed me to think through with my students the difference the original material, tactile environment makes to our understanding of First Screening. It was a straightforward enough experiment, but even now in 2015, the implications of this kind of work are far reaching and unsettling to the discipline of literary studies. The foregoing first involves turning away from close reading and from studying literary products (as surface effects), to studying instead the literary production process - looking at how a literary work was made and how the author pushed up against the limits and possibilities of particular writing media-. From there, the ramifications of such an approach start to become more obvious as soon as one realizes that learning and teaching "the how" of literary production cannot take place without access to the tools themselves in a hands-on lab environment. That said, while using hands-on work not just as an added feature but as the driving force behind teaching and research is quite new to the humanities, the production-oriented approach to creating literature has been around in one form or another since the early twentieth century (work by Futurist F.T. Marinetti [2013] and Dadaist Tristan Tzara [2005] are pertinent examples). As many are fond of pointing out, nearly all foundational media studies scholars — such as Marshall McLuhan (1964) and Friedrich Kittler (1985) — were first literary scholars. Moreover, one can read the long history of experimental writers, especially poets, as one that is inherently about experimenting with writing media-whether pens, pencils, paper or typewriters and personal computers.

Since my academic background is in twentieth century Canadian and American experimental poetry and poetics, the move to exploring the materiality of early digital poetry was a logical next step. Furthermore, once my attention turned to the intertwinement of First Screening 
with the Apple Ile $\mathrm{e}^{\mathrm{O}}$, it likewise made sense to add to the lab's collection other, comparable personal computers from the early 1980s such as the Commodore $64^{\circ 3}$-at least partly to get a sense of why bpNichol might have chosen to spend $\$ 1395$ on the $1 \mathrm{le} \mathrm{e}^{\odot}$ rather than $\$ 595$ on the $\mathrm{C} 64^{\circ}$ - . (The answer likely lies in the fact that the $1 \mathrm{e}^{\circledR}$ was one of the first affordable computers to include uppercase and lowercase along with an 80-column screen, rather than the $\mathrm{C} 64^{\mathrm{O}}$ 's 40 -column display for uppercase letters only.)

In these early years, I tried to sell the lab to the larger public by saying that it was an entity for supporting a locavore approach to sustaining digital literature — a pitch I also hoped justified our very modest online presence while also underscoring the necessity of working directly with the machines in the lab rather than accessing, say, an Apple $\mathrm{Il}^{\Theta}$ or Commodore $64^{\odot}$ emulator online. In fact, just a few years before the lab began, two online-only electronic literature directories came into being: the Electronic Literature Directory (ELD n.d.) and the Electronic Literature as a Model of Creativity (ELMCIP n.d.) -as a way to preserve and provide broad online access to works of e-literature created since the advent of the internetHowever, as I pointed out when the lab began, no archive can ever, nor should it ever aspire to, be universal and complete; and while both directories catalogue earlier works of e-literature, an obvious stumbling block that neither one has been able to entirely overcome is the material specificity of works created before the internet and the domination of the Graphical User Interface. And, as such, the materiality of a poem like First Screening cannot be preserved under the current model of online directories. Instead, what the ELD (n.d.) and the ELMCIP (n.d.) have done - in fact, all they can do- is point to works such as Nichol's, gesture to them, but not preserve them.

Thus, from 2009 until 2012, the Archaeological Media Lab maintained its modest collection of early digital literature and hardware/software from the early 80s and gradually increased its network of supporters - from Ebay ${ }^{\circ}$ sellers who had become ardent supporters of the lab, to students and faculty from disciplines ranging from Computer Science, Art, Film Studies, and English Literature, to digital archivists. However, 2012 was a turning point for the lab for a number of reasons: first, and most importantly, the lab was given a 1000 square foot space in the basement of an older home on the edge of campus, making it possible for the lab to become the open-ended, experimental space it is today with the largest collections of stillfunctioning media in North America; second, I renamed

\footnotetext{
${ }^{2}$ The Apple Ile ${ }^{\odot}$ was released by Apple Inc. in 1983 and discontinued in 1993. It had 64 KB of RAM and its operating system was DOS.

${ }^{3}$ The Commodore $64^{\circ}$ was released by Commodore Inc. in 1982 and discontinued in 1994. It had 64 KB of RAM and its operating system was Commodore BASIC.
}

the lab the Media Archaeology Lab (MAL) to better align it with the field of media archaeology I was then immersed in; and third, the MAL became a community enterprise no longer synonymous just with me - now the lab has an international advisory board of scholars, archivists, and entrepreneurs which I consult every six months, CU-Boulder faculty fellows, a regularly rotating cohort of undergraduate interns, graduate research assistants, post-graduate affiliates, and volunteers from the general public.

\section{Holdings and Actuality}

In terms of its holdings, the MAL now boasts a sprawling collection of functioning personal computers and gaming consoles from the mid-1970s through the early-2000s; games as well as educational, creative, and productivity software on cartridges, cassette tapes, and floppy disks; printed matter including journals, magazines, manuals, and books on anything related to computing and creative/humanities computing from the 1950s to the present; word processors; manual and electric typewriters; fax machines; cell phones; and a wide range of analog media from a 1910 magic lantern, a 1912 Edison Diamond Disc Phonograph ${ }^{\odot}$, to projectors, record players, 8-track players, cassette tape players, and calculators (Figures 3, 4, 5 and 6). Not surprisingly, then, the MAL continues to have a flexible acquisitions policy for as long as we have room, we continue to collect and accept donations of functioning media of all kinds. And for now, our flexibility is our strength for in the lab you can see how seemingly different media of all kinds that are conventionally seen as distinct from each other are actually part and parcel of the same line of thought. For example, the discs that came with the Edison ${ }^{\odot}$ phonograph include a prominent warning label forbidding consumers from playing Edison $^{\oplus}$ discs on any other phonograph machine; ostensibly, one would destroy the diamond point and the discs if one attempts to mix "platforms" - say, Victrola ${ }^{\circledR}$ with the Edi-

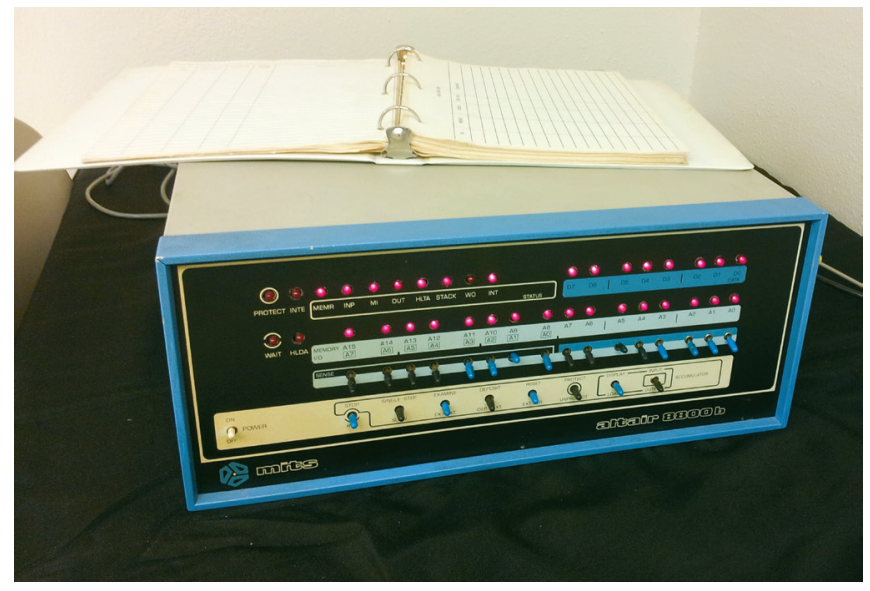

FIGURE 3. Altair@ 8800b. (Photograph: Lori Emerson, 2013; courtesy: The Media Archaeology Lab, CU-Boulder). 


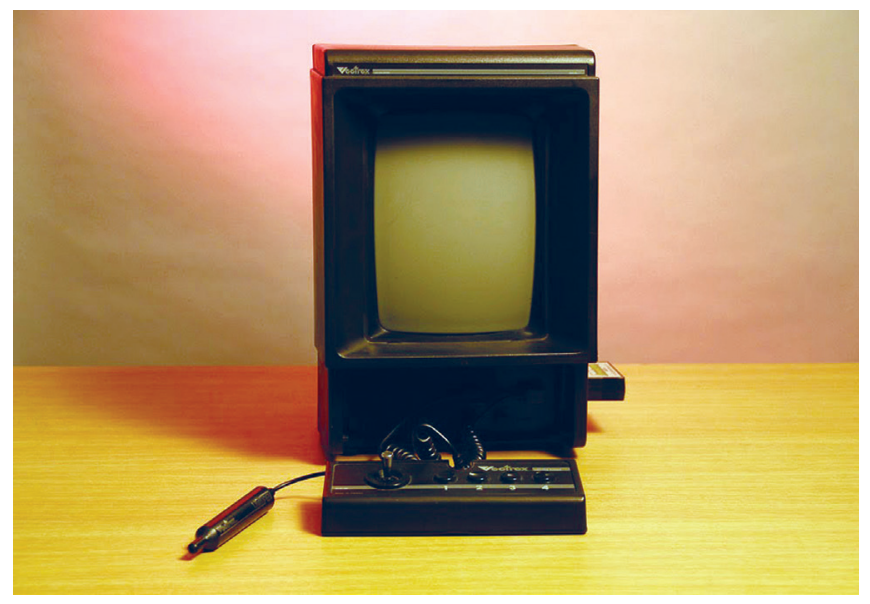

FIGURE 4. Vectrex ${ }^{\circ}$. (Photograph: Diane Bolluck, 2012; courtesy: the Media Archaeology Lab, CU-Boulder).

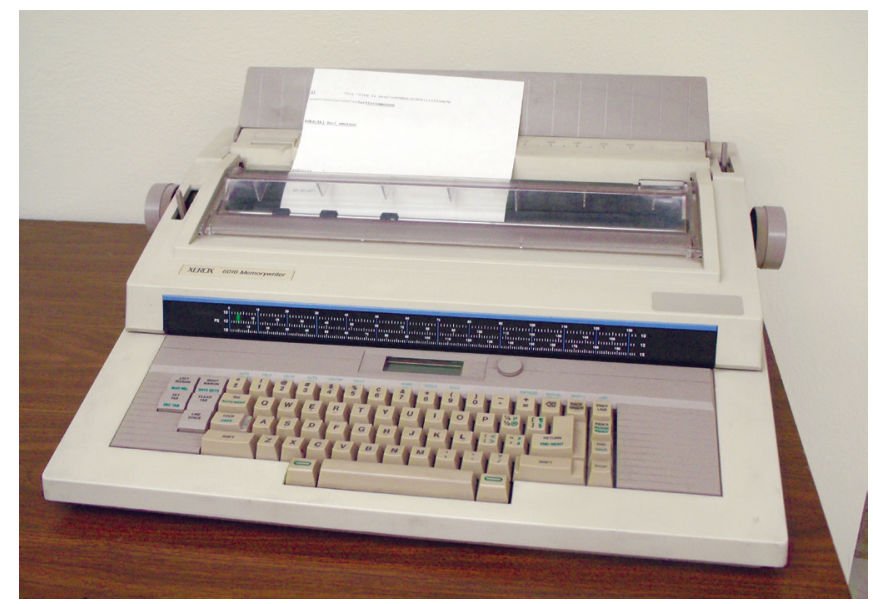

FIGURE 5. Xerox ${ }^{\ominus} 6016$ Memorywriter. (Photograph: Lori Emerson, 2013; courtesy: the Media Archaeology Lab, CU-Boulder).

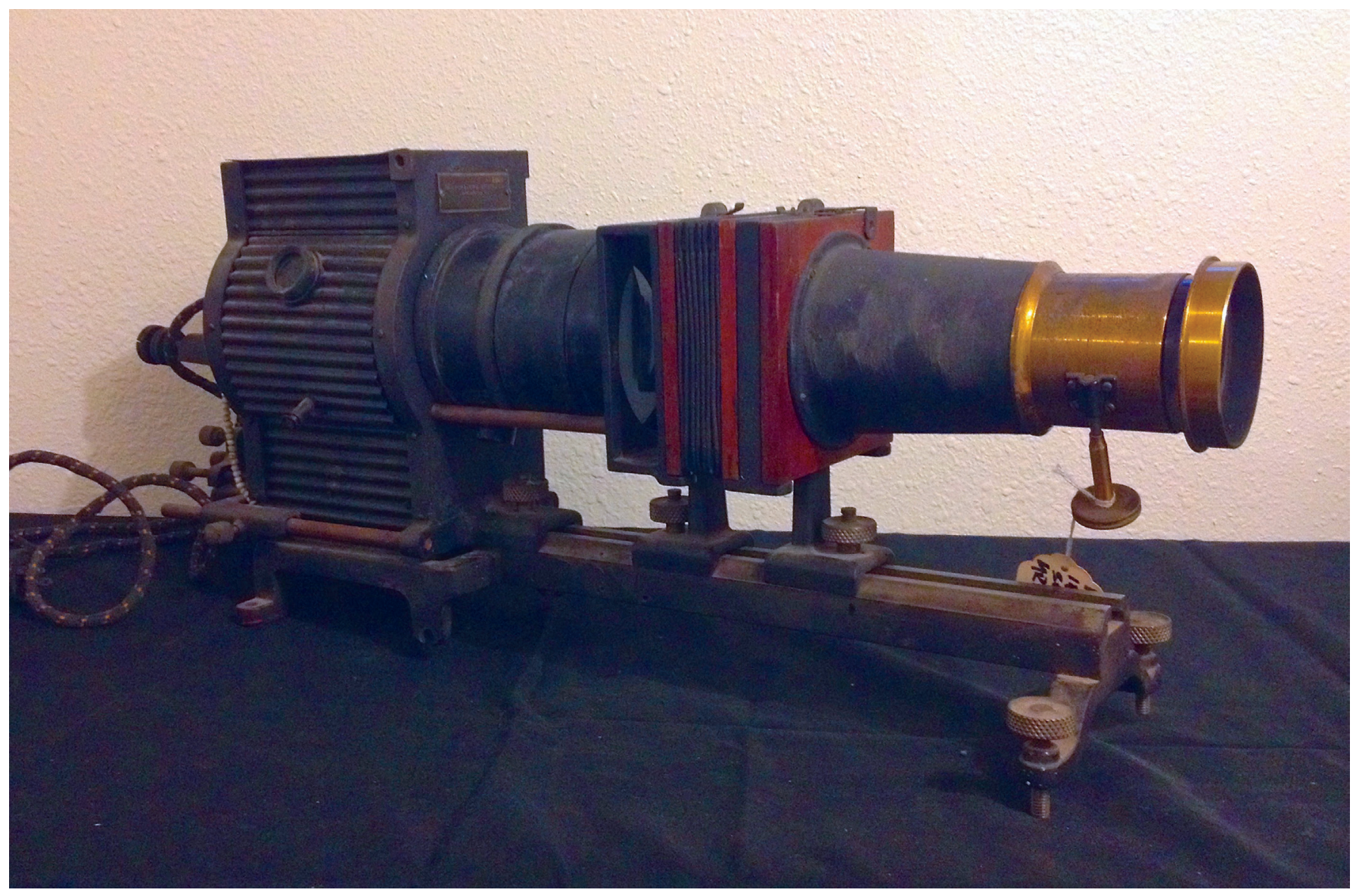

FIGURE 6. Magic Lantern. (Photograph: Lori Emerson, 2012; courtesy: the Media Archaeology Lab, CU-Boulder).

son $^{\circledR}$ machine. In other words, Edison ${ }^{\odot}$ paved the way for Bill Gates and Steve Jobs in the way he created a proprietary technology as a way of edging out the competition and preventing cross-platform compatibility.

However, despite its impressive collection of functioning media, the MAL is explicitly not a museum. Instead, it is an open-ended space for hands-on training in ac- cessioning, cataloguing, archiving, and exhibiting. It also generates research for graduate students and researchers - for example, students currently affiliated with the lab are working on projects and/or dissertation chapters on scanners, digital literature, videogame ROM (read-only memory) hacking, and early digital art/literature-. FinaIly, and perhaps most importantly, the lab also hosts an art- 
ist residency series, inaugurated by Mél Hogan ${ }^{4}$ in 2013, as yet another means by which to encourage hands-on experimentation.

\section{Conclusions}

To date, the MAL has hosted about a dozen artists and writers from North America and Europe who have produced projects ranging from games on video cassette recorder (VCR), live sound performances, distributed works of digital literature, and visual works of art.

We have come to see that having artists as well as humanists involved in the ongoing process of creating/ building the lab is an effective way to intervene in the science-dominated culture of labs that are, almost always procedurally rigid, hierarchical, as well as tightly controlled spaces closed to anyone (member of the public or member of the institution) not affiliated with the research group. In this regard, we do not want the MAL to emulate the sciences and we do not want to give our lab the veneer of scientific work as a way to legitimize ourselves or attract funding. Instead, we are intentionally creating a porous, flexible, creative space for (again) doing as an instigator for rigorous thinking in whatever register participants would like.

\section{References}

\section{ELMCIP}

n.d. Electronic Literature as a Model of Creativity, Available from [http://elmcip.net/], Accessed on 22 October 2015. ELD

n.d. Electronic Literature Directory, Available from [http:// directory.eliterature.org/], Accessed on 22 October 2015.

Hogan, Mél

n.d. Mél Hogan [web page], Available from [http://melhogan.com/website/], Accessed on 29 October 2015.

Kittler, Friedrich

1985 Discourse Networks 1800/1900, Redwood City, California, Standford University Press.

\footnotetext{
${ }^{4}$ Mél Hogan is now an Assistant Professor of Communication at the Illinois Institute of Technology (IIT) in Chicago. She teaches environmental media and graphic design, and other courses in digital media. Her research focuses on the material aspects of the Internet (Hogan n.d.).
}

Marinetti, F.T.

2013 Selected Poems and Related Prose, Luce Marinetti (ed.), New Haven, CT, Yale University Press.

McLuhan, Marshall 1964 Understanding Media, New York, McGraw-Hill. Nichol, bp

1983 First Screening [computer program poem], Toronto, Underwhich Editions.

Tzara, Tristan

2005 Chanson Dada: Tristan Tzara Selected Poems, Lee Harwood Boston (trans.), Black Widow Press.

AIMS

2013 "Appendix I: Digital Archivist Community", Library of Virginia AIMS: An Inter-Institutional Model for Stewardship, Available from [https://dcs.library.virginia.edu/ files/2013/02/AIMS_final_A4_appl.pdf], Accessed on November 2015 .

\section{Curricular Synthesis}

\section{Lori Emerson}

Media Archaeology Lab (MAL)

University of Colorado Boulder (CU-Boulder), Estados Unidos de

América

Lori.Emerson@colorado.edu

Associate Professor with a split appointment in the Department of English and the Intermedia Arts, Writing, and Performance Program (University of Colorado at Boulder [CU-Boulder], United States of America). Director of the Media Archaeology Lab (CU-Boulder). Emerson has published about media poetics as well as the history of computing, media archaeology, media theory, and digital humanities. She is currently working on two book projects: Other Networks, a history of telecommunications networks that existed before or outside of the Internet; and THE LAB BOOK: Situated Practices in Media Studies, co-written by Emerson, Jussi Parikka and Darren Wershler. Author of Reading Writing Interfaces: From the Digital to the Bookbound (University of Minnesota Press, June 2014). Also co-editor of three collections: The Johns Hopkins Guide to Digital Media, with Marie-Laure Ryan and Benjamin Robertson (2014); Writing Surfaces: The Selected Fiction of John Riddell, with Derek Beaulieu (Wilfred Laurier University Press, 2013); and The Alphabet Game: a bpNichol Reader, with Darren Wershler (Coach House Books 2007). 